\title{
Replication and Clearance of Respiratory Syncytial Virus
}

\author{
Apoptosis Is an Important Pathway of Virus Clearance after \\ Experimental Infection with Bovine Respiratory Syncytial Virus
}

\author{
Birgitte Viuff, ${ }^{*}$ Kirsten Tjørnehøj, ${ }^{\dagger}$ Lars E. Larsen, ${ }^{\ddagger}$ \\ Christine M. Røntved, ${ }^{\S}$ Åse Uttenthal, ${ }^{\dagger}$ \\ Leif Rønsholt, ${ }^{\dagger}$ and Soren Alexandersen ${ }^{\text {Tा }}$ \\ From the Department of Pharmacology and Pathobiology,* The \\ Royal Veterinary and Agricultural University, Frederiksberg, \\ Denmark; the Danish Veterinary Institute, ${ }^{\dagger}$ Lindholm, Denmark; \\ the Danish Veterinary Institute, ${ }^{\neq}$Copenhagen, Denmark; the \\ Danish Institute of Agricultural Science, ${ }^{\S}$ Tjele, Denmark; and \\ the Pirbright Laboratory, "Institute for Animal Health, Pirbright, \\ United Kingdom
}

Human respiratory syncytial virus is an important cause of severe respiratory disease in young children, the elderly, and in immunocompromised adults. Similarly, bovine respiratory syncytial virus (BRSV) is causing severe, sometimes fatal, respiratory disease in calves. Both viruses are pneumovirus and the infections with human respiratory syncytial virus and BRSV have similar clinical, pathological, and epidemiological characteristics. In this study we used experimental BRSV infection in calves as a model of respiratory syncytial virus infection to demonstrate important aspects of viral replication and clearance in a natural target animal. Replication of BRSV was demonstrated in the luminal part of the respiratory epithelial cells and replication in the upper respiratory tract preceded the replication in the lower respiratory tract. Virus excreted to the lumen of the respiratory tract was cleared by neutrophils whereas apoptosis was an important way of clearance of BRSVinfected epithelial cells. Neighboring cells, which probably were epithelial cells, phagocytized the BRSV-infected apoptotic cells. The number of both $\mathrm{CD}^{+}$and $\mathrm{CD8}+\mathrm{T}$ cells increased during the course of infection, but the $T$ cells were not found between the epithelial cells of the bronchi up until apoptosis was no longer detected, thus in the bronchi there was no indication of direct contact-dependent T-cell-mediated cytotoxicity in the primary infection. (Am J Patbol 2002, 161:2195-2207)
Human respiratory syncytial virus (HRSV) is the most common cause of serious lower respiratory tract infection in infants and young children, ${ }^{1}$ but elderly people and immunocompromised adults are also at high risk for severe HRSV infection. ${ }^{2}$ The development of effective preventive or therapeutic strategies has been hampered by a lack of knowledge of the pathogenesis of HRSV. In the 1960s, an attempt to vaccinate children with a formalininactivated HRSV vaccine failed when enhanced disease was reported after subsequent HRSV infection of vaccinated infants. ${ }^{3,4}$ A vaccine against HRSV is not currently available and a major obstacle for development of a vaccine is that the immunological mechanisms leading to either protection or enhanced disease has not been clarified. It seems that part of the illness caused by natural HRSV infection is because of the host immune response. ${ }^{5,6}$ For some years RSV serum antibodies were thought to play a role in the enhanced disease, ${ }^{7}$ but passive antibody prophylaxis has shown that antibodies cause an acceleration of virus clearance without harmful effects $^{8,9}$ although there was no improvement in the pulmonary pathology either. ${ }^{10}$ A systemic cell-mediated sensitization has also been suggested to contribute to the altered response to natural HRSV infection that occurred after use of inactivated HRSV vaccine. ${ }^{11}$ In this context the mouse model has been used intensively to study the association between T-cell subpopulations and immunemediated disease. ${ }^{12}$ However, most of this work has focused on the vaccine-enhanced disease whereas there is a lack of investigation into the pathogenesis of the primary infection. A better understanding of the pathogenesis after primary infection will probably help in solving the conundrum of the vaccine-enhanced disease.

HRSV is an enveloped RNA virus and is classified in the subfamily Pneumovirinae of the family Paramyxoviridae. Bovine respiratory syncytial virus (BRSV) is a closely

Supported by the Danish Agricultural and Veterinary Research Council and Research Centre for the Management of Animal Production and Health.

Accepted for publication September 12, 2002.

Address reprint requests to Birgitte Viuff, Department of Pharmacology and Pathobiology, The Royal Veterinary and Agricultural University, Ridebanevej 3, DK-1870, Frederiksberg C, Denmark. E-mail: bmv@kvl.dk. 
related virus belonging to the same subfamily as HRSV. As is HRSV in humans, BRSV is the most common cause of lower respiratory tract disease in young calves, and the clinical and epidemiological characteristics of BRSV closely reflect those of HRSV.

We have established an experimental model of BRSV in calves to study the pathogenesis of the RSV infection. The primary advantage of this model is that we are studying the infection in the natural host. Therefore, we see a high level of viral replication compared to other experimental models, as for instance the mouse model that has a restricted permissiveness. ${ }^{13}$ Thus, the calf model is an excellent model for studying RSV replication and clearance of virus.

In the present study, we describe the replication of BRSV in calves at different times after inoculation, and in which cells the replication takes place, and the important pathways of viral clearance. Furthermore, the influx of T lymphocytes, neutrophils, and macrophages to the lung are examined.

\section{Materials and Methods}

\section{Calves}

Male Jersey calves (1 to 2 weeks of age) were derived from two closed herds and were kept in isolation until euthanasia. They were monitored weekly for IgM and $\lg _{1}$ antibodies to BRSV as described ${ }^{14}$ and they were free of clinical signs of respiratory tract disease at the time of inoculation. None of the calves experienced BRSV infection before inoculation. The calves were inoculated at the age of $\sim 3$ months. A total of 32 calves were included in this study of which 24 were inoculated with BRSV and 8 were mock-inoculated. The inoculation was divided into four experiments (experiments IV, IX, XI, and $X I V$ ) and in each experiment all of the calves were inoculated on the same day. Inoculum were either lung wash fluid from a calf infected experimentally with a field isolate of BRSV (used for experiment IV) or cell culture material of BRSV-infected fetal bovine lung cells (used for experiments IX, XI, and XIV) as described. ${ }^{15,16}$ Lung wash fluid from an uninfected calf served as mock inoculum in experiment IV, whereas uninfected cell culture of fetal bovine lung cells was used as mock inoculum for the remainder. ${ }^{16}$ The calves were only inoculated once by combined intratracheal and aerosol route. A dose of $10^{4.6}$ (experiment IV) to $10^{5.2}$ (experiment IX) tissue culture infectious dose ${ }_{50}\left(T_{C I D}\right)$ diluted to $5 \mathrm{ml}$ in phosphatebuffered saline (PBS) was administered throughout 10 minutes through a mask covering nostrils and mouth (Waechtomat inhalator VM 82, Kruse, Denmark, most droplets less than $3 \mu \mathrm{m}$ ). Subsequently, a dose of $10^{4.6}$ to $10^{5.2} \mathrm{TCID}_{50}$ diluted to $20 \mathrm{ml}$ in PBS was injected into the trachea. All calves were housed together until the time of inoculation then the control calves were moved to separate, but similar isolation units. To investigate the influence of other agents, three calves in experiment XI were treated daily with $2.5 \mathrm{mg} / \mathrm{kg}$ of enrofloxacin (Baytril,
Bayer) from 1 day before inoculation until the calves were killed on postinoculation day (PID) 6 .

\section{Necropsy}

The calves were anesthetized using pentobarbital and euthanized by exsanguination on PIDs $2,4,6,8$, 15, or 30. The lungs and trachea were immediately removed from the animals and photographs were taken of the ventral and dorsal sides of the lungs. The extent of consolidated lung tissue was scored from 0 to 5 , in which the score of 0 was given to lungs completely free of lesions. The score of 1 was given to lungs with a few spots ( 1 to $5 \%$ ) of consolidated lung tissue, 2 to lungs with 5 to $15 \%$, 3 to lungs with 15 to $30 \%$, and 4 to lungs with 30 to $50 \%$ of consolidated tissue. The score of 5 was given to lungs in which most of the tissue in the cranial, medial, and accessory lobes, and at least a third of the caudal lobes consisted of consolidated tissue $(>50 \%)$.

Tissue samples from eight predetermined sites of the right lung, ${ }^{17}$ trachea, nasal epithelium, In. tracheobronchealis, tonsilla palatina, and spleen were fixed in $10 \%$ neutral-buffered formalin. Furthermore, tonsilla pharyngea from the calves XIV-1 to XIV-4 was also fixed in formalin. The left lung and lung lavage fluid were investigated for infection with BRSV, parainfluenza virus type 3 (PI3), bovine coronavirus, bovine adenovirus, and bovine viral diarrhea virus as previously described. ${ }^{16,18}$ Swabs from the tracheal bronchus were used for mycoplasma examinations and samples from lung, liver, and spleen for bacteriological examinations as described. ${ }^{19}$

One calf, XI-9, was killed after 45 minutes and necropsy was performed as described above except that lung lavage of the left lung was not performed. Instead lung samples from six different sites of the left lung as well as the eight lung samples from the right lung were fixed in formalin. Furthermore, investigation for infection with other virus, mycoplasma, and bacteria was not performed for this calf.

\section{Immunohistochemistry}

Demonstration of BRSV antigen was performed on formalin-fixed tissue as described before. ${ }^{20}$ Briefly, a biotinylated bovine anti-BRSV hyperimmuneserum ${ }^{18}$ was used as primary antibody followed by incubation with streptavidin and biotinylated alkaline phosphatase (K391; DAKO, Glostrup, Denmark). Fast Red (KemEnTec, Copenhagen, Denmark) was used as substrate and a biotinylated bovine anti-PI3 hyperimmuneserum served as negative control. Immunohistochemistry for detection of BRSV antigen was performed on all sections fixed in formalin from all of the animals. Immunohistochemistry on the lung sections was performed twice. To generate the score for the number of BRSV-positive cells, the whole section from the eight standardized areas of the lungs was evaluated. Three sections with different scores were used as internal control and were included in every batch of immunohistochemistry. The number of positive cells in the sections was estimated according to these three 
sections. The sections were $\sim 1$ by $2 \mathrm{~cm}$ and although they were not exactly the same size, the average of eight sections equalized the difference.

CD4-positive cells were demonstrated in formalin-fixed sections by an anti-bovine CD4 monoclonal antibody (clone CACT83B; VMRD, Pullman, WA). After deparaffination the sections were blocked in $0.6 \%$ hydrogen peroxide in Tris-buffered saline (TBS; 0.05 mol/L Tris, pH 7.5, $0.15 \mathrm{~mol} / \mathrm{L} \mathrm{NaCl}$ ), rinsed in TBS and pretreated 5 minutes with $0.018 \%$ protease (P8038, Sigma) in TBS. The sections were rinsed in TBS and blocked in 5\% normal swine serum in TBS (TBS-NSS). The primary antibody was diluted 1:10 in TBS-NSS, and sections were incubated overnight at $4^{\circ} \mathrm{C}$. This incubation was followed by 30 minutes of incubation with rabbit anti-mouse immunoglobulins (Z259, DAKO) diluted 1:25 in TBS-NSS and 30 minutes of incubation with peroxidase-anti-peroxidase complex, mouse monoclonal (P850, DAKO) diluted 1:50 in TBS-NSS. The sections were washed three times for 5 minutes in TBS after each incubation. Finally, the sections were incubated for 20 minutes with 3,3'-diaminobenzidine + (DAKO) and counterstained for 10 seconds in Harris' hematoxylin.

CD8-positive cells were detected as described for the CD4-positive cells. Two anti-bovine CD8 monoclonal antibodies [clone BAQ111A and BAT82A (VMRD), reacting with the $\alpha$ - and $\beta$-chain, respectively] were mixed and both used at a 1:20 dilution in TBS-NSS. The whole sections from three of the eight standard areas of the lung were examined to obtain the score for the number of $\mathrm{CD}^{+}{ }^{-}$and $\mathrm{CD} 8+-$-positive cells using internal control as described above. Immunohistochemical demonstration of Haemophilus somnus and Pasteurella multocida was attempted in the calves from which these bacteria had been isolated by the method described by Tegtmeier and colleagues. ${ }^{21}$

\section{Double Immunohistochemistry}

Detection of BRSV antigen was followed by demonstration of either epithelial cells or macrophages. BRSV antigen was visualized by incubation for 1 hour with biotinylated bovine anti-BRSV hyperimmuneserum followed by 30 minutes of incubation with streptavidin- $\beta$-galactosidase (Boehringer Mannheim, Mannheim, Germany). Sections were then incubated for 1 hour with X-Gal substrate (HistoMark, Kirkegaard \& Perry Laboratories, Gaithersburg).

For demonstration of BRSV-positive epithelial cells a monoclonal antibody against cytokeratin (MNF116, DAKO) was used. After development of the BRSV signal, as described above, sections were stored overnight in TBS at $4^{\circ} \mathrm{C}$ followed by 5 minutes of protease treatment as described above and a 1-hour incubation with the primary antibody diluted 1:50 in TBS-NSS. Rabbit antimouse (Z259, DAKO) diluted 1:25 and alkaline phosphatase-anti-alkaline phosphatase complex (D651, DAKO) diluted 1:50 were used as secondary and tertiary antibodies, respectively, both incubated for 30 minutes. The sections were then incubated for 5 minutes with Fast
Red (KemEnTec) and counterstained for 1 second in Harris' hematoxylin.

An anti-human-CD68 monoclonal antibody (EBM11, DAKO) was used as primary antibody for demonstration of BRSV-positive macrophages. Sections were kept overnight in TBS at $4^{\circ} \mathrm{C}$ followed by 5 minutes of protease treatment and were then incubated overnight at $4^{\circ} \mathrm{C}$ with anti-CD68 diluted 1:50 in TBS-NSS. The reaction was demonstrated with alkaline phosphatase-anti-alkaline phosphatase/Fast Red as described above for the cytokeratin staining. Double-positive cells were purple and could easily be differentiated from single-positive cells that were either clear blue (X-gal) or red (Fast Red).

\section{In Situ Hybridization}

The in situ hybridization was performed on formalin-fixed sections as previously described. ${ }^{20}$ The probes were strand-specific RNA probes radiolabeled with ${ }^{35}$ S-UTP, and negative sense probes were used to demonstrate replication. Clones of the middle part of the $\mathrm{N}$ and $\mathrm{F}$ genes, as described previously, ${ }^{17,20}$ were used as DNA template for the probes. The probes were used separately or in combination.

\section{Demonstration of Apoptosis}

An In Situ Cell Death Detection Kit AP from Boehringer Mannheim (terminal dUTP nick-end labeling reaction) was used to demonstrate apoptotic cells in formalin fixed tissue sections. After deparaffination, sections were treated with $10 \mu \mathrm{g} / \mathrm{ml}$ of proteinase $\mathrm{K}$ (Boehringer Mannheim) in $10 \mathrm{mmol} / \mathrm{L}$ of Tris, $\mathrm{pH} 7.5$, and $2 \mathrm{mmol} / \mathrm{L}$ of $\mathrm{CaCl}_{2}$ for 10 minutes at $37^{\circ} \mathrm{C}$. The sections were rinsed twice with TBS, and then the protocol from the manufacturer was followed, except that TBS was used instead of PBS. The sections were developed with Fast Red (KemEnTec) for 10 minutes at room temperature.

\section{Results}

\section{Clinical Signs and Macroscopic Changes}

As in naturally occurring BRSV infection, there were individual differences in the severeness of the disease. Clinical signs of disease ranged from mild coughing to a severe respiratory distress. ${ }^{16}$ Coughing, hyperpnea, tachypnea, and anorexia were the most prominent clinical features. The clinical picture corresponded well to the recorded pathological changes because spontaneous coughing in some BRSV inoculated calves started on PIDs 3 to 4 and the most severe clinical signs were seen from PID 7. In experimental infection XIV, two calves died at PIDs 8 and 9 despite antibiotic and anti-inflammatory treatment (calves not included).

Gross lesions in these experimentally BRSV-infected calves were as described for naturally BRSV-infected calves. ${ }^{20,22}$ The changes progress from a few small lobular areas of consolidation on PID 2 to total consolidation of the cranial, middle, accessory, and part of the caudal 
Table 1. Results from BRSV-Inoculated Calves

\begin{tabular}{|c|c|c|c|c|c|c|c|c|}
\hline \multirow{2}{*}{$\begin{array}{l}\text { Calf } \\
\text { no. }^{*}\end{array}$} & \multirow[b]{2}{*}{ PID } & \multirow{2}{*}{$\begin{array}{c}\text { Macroscopic } \\
\text { changes } \\
\text { (score) }\end{array}$} & \multirow{2}{*}{$\begin{array}{c}\text { Other agents at } \\
\text { necropsy }\end{array}$} & \multicolumn{3}{|c|}{ BRSV antigen (score) $)^{\dagger}$} & \multirow{2}{*}{$\begin{array}{l}\text { CD4+ } \\
\text { T cells } \\
(\text { score })^{\ddagger}\end{array}$} & \multirow{2}{*}{$\begin{array}{c}\text { CD8+ } \\
\text { T cells } \\
\text { (score) })^{\ddagger}\end{array}$} \\
\hline & & & & Bronchi & Bronchioles & Alveoli & & \\
\hline$X I-9^{\S}$ & 0 & 0 & ND & 0 & 0 & 0 & ND & ND \\
\hline IX-2 & 2 & 1 & M.d., U. & 0.5 & 0 & 0 & 3 & 3 \\
\hline IX-3 & & 1 & M.d., U. & 0.5 & 0 & 0 & 1 & 1 \\
\hline IV-2 & 4 & 3 & M.d., M.b. & 3.4 & 2.0 & 0.9 & 2 & 3 \\
\hline IV-3 & & 2 & M.d., U. & 2.3 & 2.0 & 1.4 & 2 & 3 \\
\hline IX-5 & & 1 & M.d., U. & 1.9 & 0.5 & 0.3 & 1 & 1 \\
\hline IX-6 & & 1 & M.d., U. & 2.3 & 0.4 & 0.1 & 2 & 2 \\
\hline IX-8 & 6 & 2 & M.d., U., H. somn. & 1.8 & 1.5 & 1.5 & 1 & 2 \\
\hline IX-9 & & 5 & M.d., U., H. somn. & 2.4 & 3.5 & 3.5 & 3 & 3 \\
\hline $\mathrm{XI}-1^{\pi}$ & & 4 & - & 2.0 & 1.8 & 2.6 & 2 & 3 \\
\hline $\mathrm{XI}-2^{\mathrm{T}}$ & & 1 & - & 2.3 & 2.4 & 2.3 & 2 & 2 \\
\hline $\mathrm{XI}-3^{\pi}$ & & 2 & U. & 0.8 & 0.1 & 0 & 2 & 3 \\
\hline XIV-2 & & 3 & M.d., P. mult. & 3.6 & 3.8 & 3.2 & 1 & 1 \\
\hline XIV-3 & & 5 & M.d., M.b., P. mult. & 4.4 & 4.4 & 3.6 & 2 & 2 \\
\hline XIV-4 & & 3 & M.d., M.b. & 4.0 & 3.0 & 2.6 & 2 & 2 \\
\hline IV-5 & 8 & 4 & M.d. & 0 & 0.5 & 1.5 & 4 & 5 \\
\hline IV-6 & & 4 & M.d., U. & 0 & 0 & 0.8 & 2 & 3 \\
\hline $\mid X-11$ & & 4 & M.d., U., P. mult. & 0 & 0 & 0.8 & 3 & 4 \\
\hline IX-12 & & 3 & M.d., M.b. & 0 & 0 & 0 & 3 & 4 \\
\hline IV-8 & 15 & 4 & M.d., P. avium & 0 & 0 & 0 & 3 & 4 \\
\hline IV-9 & & 1 & M.d. & 0 & 0 & 0 & 1 & 2 \\
\hline IV-10 & 30 & 2 & M.d. & 0 & 0 & 0 & 4 & 5 \\
\hline IV-11 & & 1 & M.d. & 0 & 0 & 0 & 1 & 1 \\
\hline IV-12 & & 1 & M.d. & 0 & 0 & 0 & 1 & 1 \\
\hline
\end{tabular}

*First part of the calf number refers to the experiment number; last part of the number is the individual calf number. The inoculum in experiment number IV consisted of lung wash fluid from a BRSV-infected calf whereas BRSV-infected fetal bovine lung cells were used for inoculum in experiments IX, XI, and XIV.

${ }^{+}$The BRSV antigen score is the average of the score from the eight evaluated areas of the lungs.

FThe CD4+ and CD8 + scores are the average of a score obtained from the same three different areas of the lung.

$\$$ Calf XI-9 was killed 45 minutes after inoculation.

IThe three BRSV-infected calves in experiment XI were treated with enrofloxacin from 1 day before inoculation until the calves were killed on PID 6.

ND: Not done; U.: Ureaplasma; M.d.: Mycoplasma dispar; M.b.: Mycoplasma bovirhinis; H. Somn.: Haemophilus somnus; P. mult.: Pasteurella multocida; P. avium: Pasteurella avium.

lobes in the most severely affected animals killed on PIDs 6 to 8 . Interstitial edema and mucupurulent exudate in trachea and bronchi were seen from PID 4, whereas emphysema was present in a few severely affected calves killed on PID 6 and in three of five calves killed on PID 8. Emphysema was especially pronounced in the caudal lobes but was also seen in the middle and accessory lobes. Consolidated areas persisted in one of two calves killed on PID 15 and in one of three calves killed on PID 30. The score for the extent of macroscopic changes in the lung obtained for each animal is given in Table 1, and a schematic outline for the BRSV-infected calves is given in Figure $1 \mathrm{~A}$.

Clinical signs were not observed in mock-inoculated calves. Two mock-inoculated calves (killed on PIDs 2 and 8) had no macroscopic changes in the lungs, whereas one or a few small lobular consolidated areas were observed in the remainder of the control calves (Table 2).

\section{Microscopical Findings and Sites of BRSV Replication}

All of the BRSV-infected calves showed more or less severe bronchopneumonia, but depending on the PID, there was a shift in the main lesions from bronchitis on PIDs 2 to 4 to bronchiolitis and alveolitis on PIDs 6 to 8 .
Characteristically, the microscopical changes correlated with sites of BRSV replication.

Neither BRSV replication nor antigen could be demonstrated in the calf killed after 45 minutes (Table 1), whereas replication of BRSV in calves killed on PID 2 was demonstrated in a few scattered bronchial epithelial cells by in situ hybridization with a negative sense probe (Figure 2A), and immunohistochemistry revealed BRSV antigen in the same cells on parallel sections (Figure 2B). Consequently, applied to epithelial cells, demonstration of BRSV antigen reflects replication. Neither BRSV replication nor antigen was detected in bronchiolar or alveolar epithelial cells on PID 2 (Table 1).

Replication of BRSV in the bronchial epithelial cells was more pronounced on PID 4 as the whole epithelial lining of many of the large bronchi was replicating the virus. BRSV antigen was mainly demonstrated in the luminal part of the BRSV replicating epithelial cells including the cilia where a large amount of antigen could be demonstrated (Figure 2C). The bronchial epithelial cells appeared mainly intact, but desquamation of the epithelium was occasionally seen. In contrast to PID 2, replication was also observed in a few bronchiolar and alveolar epithelial cells. This replication had a lobular distribution.

A severe aggravation in lesions was observed in the lungs of calves killed on PID 6 compared to earlier PIDs. 

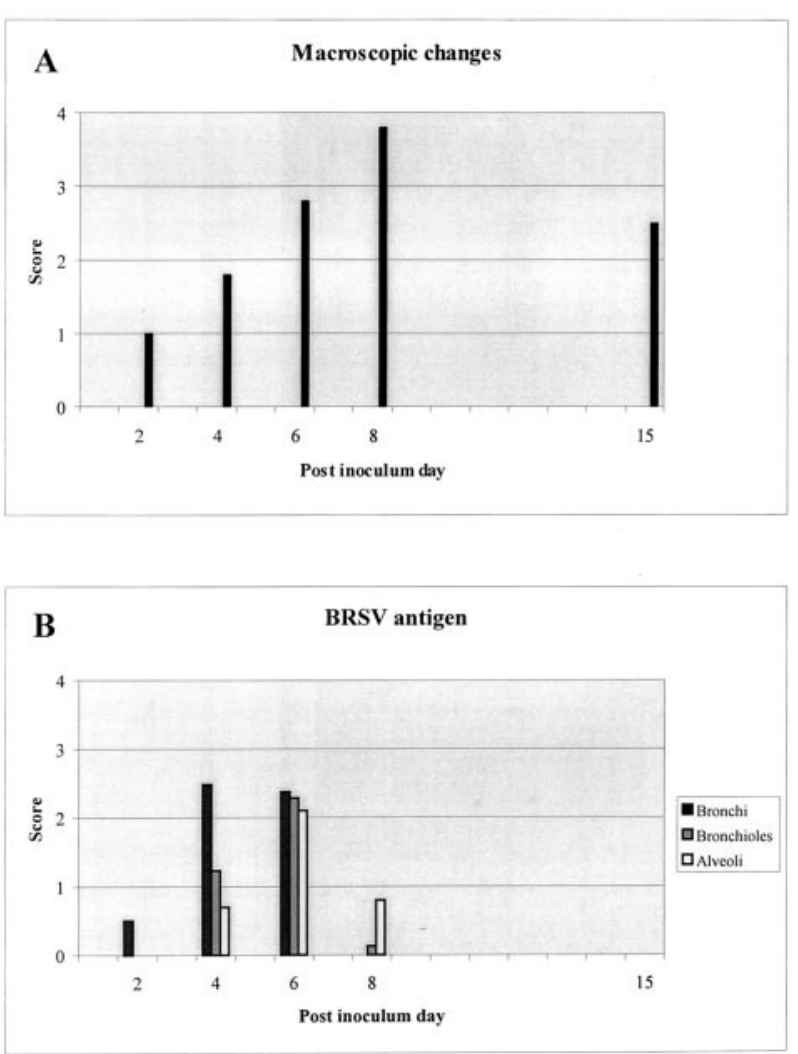

Figure 1. A: Schematic outline of the presence of macroscopic changes. The figure is based on an average of the score given in Table 1. B: Schematic outline of the presence of BRSV antigen (reflecting replication) in the bronchial, bronchiolar, and alveolar epithelial cells. The BRSV antigen score is an average of scores for the animals killed the same PID (see Table 1).

Especially the alveolitis, with cellular infiltration into alveoli, was more pronounced and edema was observed in some of the alveoli. Bronchitis with hyperplasia of the bronchial epithelium was still present. Many of the bronchial epithelial cells had lost their cilia and the epithelium seemed irregular. The microscopical findings correlated with an extensive replication of BRSV in bronchial, bronchiolar, and alveolar cells on PID 6 (Figure 2D).

In most calves killed on PID 8, the bronchial epithelium started to look regular again, although cilia were still absent. Neither BRSV replication nor antigen could be demonstrated in the bronchial epithelial cells, whereas a limited number of bronchiolar and alveolar epithelial cells still replicated BRSV. Bronchioles and alveoli and also some of the bronchi were plugged with cellular exudate. Furthermore, edema and fibrin were pronounced in some alveoli.

From PID 4 to PID 8 with peak on PID 6, a large number of syncytia was seen in bronchioles and alveoli, but not in bronchi. Immunostaining using an antibody against cytokeratin revealed that the syncytia were of epithelial origin and in situ hybridization demonstrated that they supported replication of BRSV.

In calves killed on PID 15, the overall picture was that of repair. Neither BRSV replication nor antigen could be demonstrated although pathological changes were still present. Bronchiolitis obliterans was observed in some lobules often causing collapse of surrounding alveoli.

BRSV could not be detected in calves killed on PID 30 and two of three calves had no pathological changes. The changes in the third calf were mild and characterized by hyperplasia of bronchial-associated Iymphoid tissue and a limited number of neutrophils in bronchioles and alveoli. Furthermore, bronchiolitis obliterans was occasionally observed. A schematic outline of the replication in the lung of BRSV-infected calves is given in Figure 1B.

Based on morphology it was difficult to determine which alveolar cells replicated BRSV. Replication of BRSV in alveolar type I epithelial cells were easily recognizable (Figure 2E), whereas large mononuclear BRSVreplicating cells protruding from the alveolar wall or situated in the alveolar lumen could be alveolar type II epithelial cells as well as alveolar macrophages. Double immunohistochemistry using X-gal and Fast Red as substrate made it possible to clearly distinguish the two different single-stained populations from the double-positive cells (Figure 2F). The double immunohistochemistry demonstrated that alveolar type II epithelial cells contained large amounts of BRSV antigen (Figure 2G). These cells corresponded to the large cells replicating BRSV seen by in situ hybridization. In contrast, when alveolar macrophages were demonstrated using an antibody against CD68, only a few of the macrophages contained

Table 2. Results from Mock-Inoculated Calves

\begin{tabular}{|c|c|c|c|c|c|c|c|c|}
\hline \multirow[b]{2}{*}{ Calf no.* } & \multirow[b]{2}{*}{ PID } & \multirow{2}{*}{$\begin{array}{c}\text { Macroscopic } \\
\text { changes } \\
\text { (score) }\end{array}$} & \multirow{2}{*}{$\begin{array}{l}\text { Other agents } \\
\text { at necropsy }\end{array}$} & \multicolumn{3}{|c|}{ BRSV antigen (score) ${ }^{\dagger}$} & \multirow{2}{*}{ 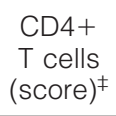 } & \multirow{2}{*}{$\begin{array}{c}\text { CD8+ } \\
\text { T cells } \\
\text { (score) }^{\ddagger}\end{array}$} \\
\hline & & & & Bronchi & Bronchioles & Alveoli & & \\
\hline $\mid X-1$ & 2 & 0 & U. & 0 & 0 & 0 & 1 & 1 \\
\hline IV-1 & 4 & 1 & U. & 0 & 0 & 0 & 1 & 1 \\
\hline IX-4 & & 1 & - & 0 & 0 & 0 & 1 & 1 \\
\hline IX-7 & 6 & 1 & M.d., U. & 0 & 0 & 0 & 1 & 1 \\
\hline XIV-1 & & 1 & M.d. & 0 & 0 & 0 & 1 & 1 \\
\hline IV-4 & 8 & 0 & M.d., & 0 & 0 & 0 & 1 & 1 \\
\hline IX-10 & & 1 & M.d., M.b. & 0 & 0 & 0 & 1 & 1 \\
\hline IV-7 & 15 & 1 & M.d. & 0 & 0 & 0 & 1 & 1 \\
\hline
\end{tabular}

*First part of the calf number refers to the experiment number; last part of the number is the individual calf number. The inoculum in experiment number IV consisted of lung wash fluid from an uninfected calf whereas uninfected fetal bovine lung cells were used for inoculum in experiments IX, $\mathrm{XI}$, and XIV.

TThe BRSV antigen score is the average of the score from the eight evaluated areas of the lungs.

FThe CD4+ and CD8+ scores are the average of a score obtained from the same three different areas of the lung.

U.: Ureaplasma; M.d.: Mycoplasma dispar; M.b.: Mycoplasma bovirhinis. 

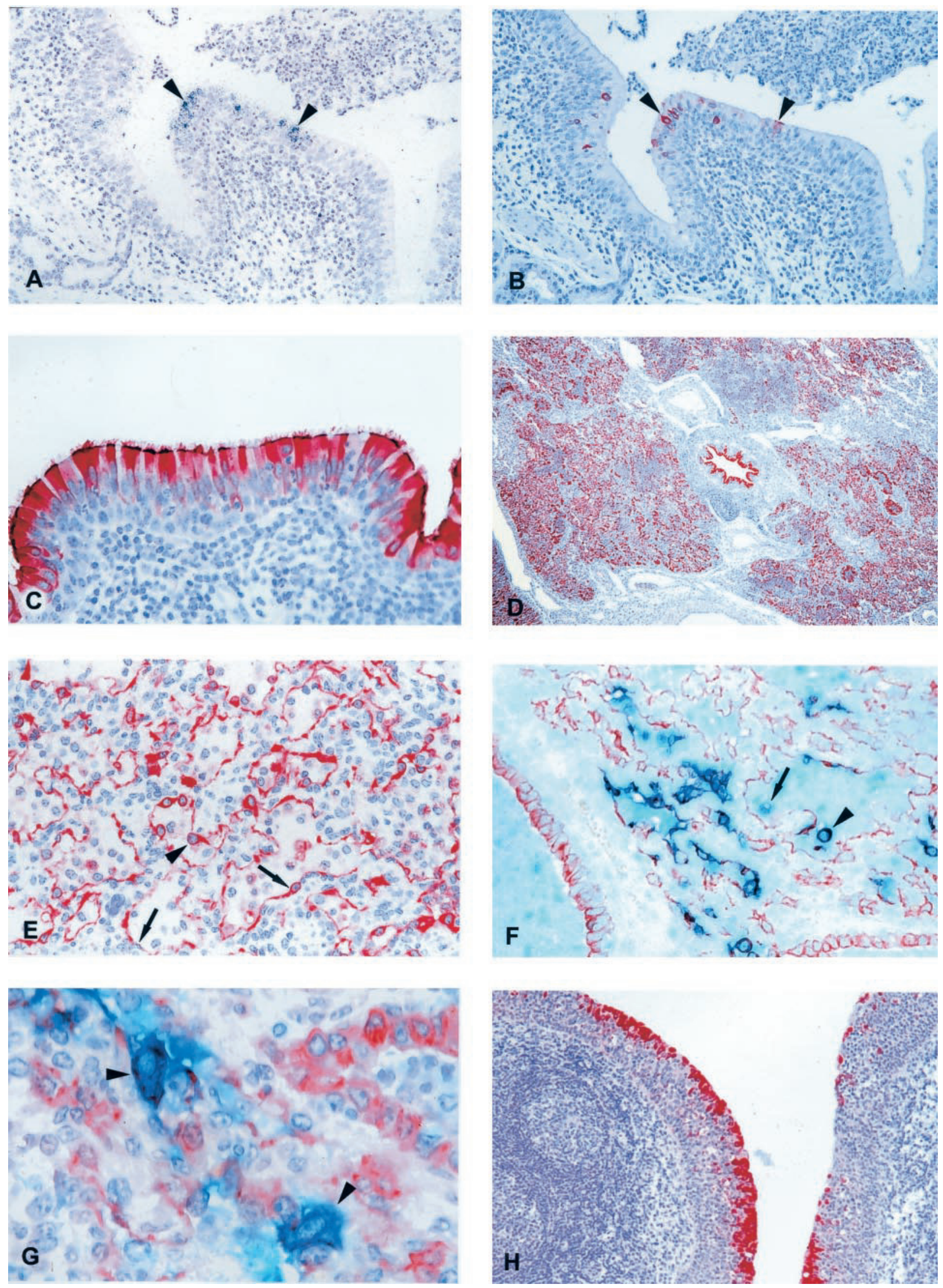

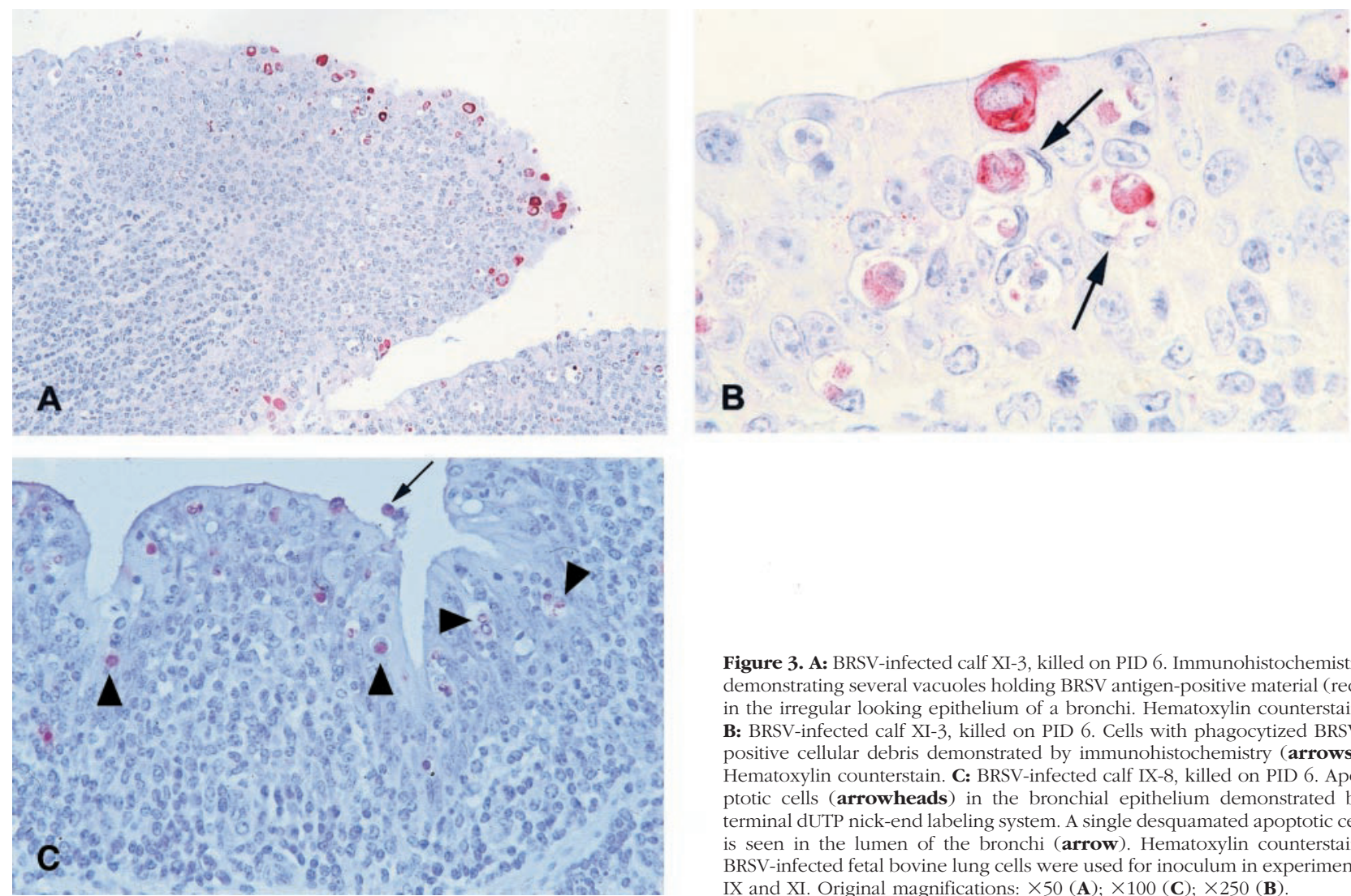

Figure 3. A: BRSV-infected calf XI-3, killed on PID 6. Immunohistochemistry demonstrating several vacuoles holding BRSV antigen-positive material (red) in the irregular looking epithelium of a bronchi. Hematoxylin counterstain. B: BRSV-infected calf XI-3, killed on PID 6. Cells with phagocytized BRSVpositive cellular debris demonstrated by immunohistochemistry (arrows). Hematoxylin counterstain. C: BRSV-infected calf IX-8, killed on PID 6. Apoptotic cells (arrowheads) in the bronchial epithelium demonstrated by terminal dUTP nick-end labeling system. A single desquamated apoptotic cell is seen in the lumen of the bronchi (arrow). Hematoxylin counterstain. BRSV-infected fetal bovine lung cells were used for inoculum in experiments IX and XI. Original magnifications: $\times 50(\mathbf{A}) ; \times 100(\mathbf{C}) ; \times 250(\mathbf{B})$.

BRSV antigen and the signal from the BRSV antigen was weak compared to the signal obtained from epithelial cells.

In addition to the epithelium of the lung, nasal and tracheal epithelium also replicated BRSV in the luminal part of the epithelial cells. The course of replication in these epithelial cells was similar to what was seen in the bronchial epithelium.

Replication of BRSV was not demonstrated outside the respiratory tract. Cells in the bronchial-associated lymphoid tissue and regional lymph nodes did not replicate BRSV although the lymphoid tissue was stimulated. Likewise, replication was not demonstrated in tonsilla palatina. However, the epithelial cells covering tonsilla pha- ryngea (tonsilla pharyngea is in contrast to tonsilla palatina covered by respiratory epithelium) strongly supported replication in calves XIV-2, -3, and -4 killed on PID 6 (Figure $2 \mathrm{H}$ ). The course of this replication is not known because we have only examined this tonsil in these few animals. The lymphoid tissue below the epithelium did not replicate BRSV.

These results demonstrate that replication of BRSV starts in the upper respiratory tract including nasal, tracheal, and bronchial epithelium followed by replication in bronchiolar and alveolar epithelium $\sim 2$ days later. The replication takes place in the epithelial cells whereas BRSV antigen rarely was found in the alveolar macrophages.

\footnotetext{
Figure 2. A: Lung section from BRSV-infected calf IX-2, killed on PID 2. Replication of BRSV is demonstrated by in situ hybridization using a negative sense probe Black silver grains cover positive cells (arrowheads). Hematoxylin counterstain. B: Parallel section to A. BRSV antigen is demonstrated by immunohistochemistry. The red BRSV antigen-positive cells correspond to cells replicating BRSV in Figure 1A (arrowheads). Hematoxylin counterstain. C: BRSV-infected calf IX-5, killed on PID 4. BRSV antigen, reflecting replication, is demonstrated in most bronchial epithelial cells. Notice the high amount of antigen in the cilia. Immunohistochemistry, BRSV antigen-positive cells are red. Hematoxylin counterstain. D: Extensive numbers of bronchial, bronchiolar, and alveolar cells containing BRSV antigen (reflecting replication) are seen in BRSV-infected calf XIV-3, killed on PID 6. Immunohistochemistry, BRSV antigen-positive cells are red. Hematoxylin counterstain. E: BRSV-infected calf XIV-2, killed on PID 6. BRSV antigen (reflecting replication) is recognizable in alveolar type I epithelial cell (arrows) whereas the large protruding cell (arrowhead) could be an alveolar type II epithelial cell or an alveolar macrophage. Immunohistochemistry, BRSV antigen-positive cells are red. Hematoxylin counterstain. F: BRSV-infected calf IV-5, killed on PID 8. Double immunohistochemistry using anti-cytokeratin and anti-BRSV antibodies. Epithelial cells are red whereas BRSV antigen-positive cells are clear blue. Double-positive cells (BRSV antigen-positive epithelial cells) become purple. Several double-positive BRSV-replicating epithelial cells are seen one of which is situated in an alveoli and could be mistaken for an alveolar macrophage (arrowhead). Also a single-positive, BRSV antigen-containing (blue) cell is situated in the alveoli (arrow). These cells were very rarely seen, but are probably alveolar macrophages containing BRSV antigen. No counterstain. G: BRSV-infected calf IV-5, killed on PID 8. Double immunohistochemistry using anti-cytokeratin and anti-BRSV antibodies. Two large double-positive alveolar type II epithelial cells replicating BRSV are seen (arrowheads). Hematoxylin counterstain. H: BRSV-infected calf XIV-3, killed on PID 6. BRSV antigen, reflecting replication, is demonstrated in the epithelial cells covering tonsilla pharyngea, whereas there is no replication in the lymphoid tissue below the epithelium. Immunohistochemistry, BRSV antigen-positive cells are red. First part of the calf number refers to the experiment number; last part of the number is the individual calf number. The inoculum in experiment number IV consisted of lung wash fluid from a BRSV-infected calf whereas BRSV-infected fetal bovine lung cells were used for inoculum in experiments IX, XI, and XIV. Original magnifications: $\times 10(\mathbf{D})$; $\times 50$ $(\mathbf{A}, \mathbf{B}$, and $\mathbf{H}) ; \times 100(\mathbf{C}, \mathbf{E}$, and $\mathbf{F}) ; \times 250(\mathbf{G})$.
} 


\section{Clearance of Virus}

Analogous to the BRSV replication, the clearance of virus first occurred in the proximal part of the respiratory tract. On PID 6 the epithelium of the bronchi looked irregular and several vacuoles containing BRSV antigen-positive material were observed (Figure 3A). The vacuoles were situated in the cytoplasm of cells with a flat peripherally placed nucleus and contained phagocytized cellular debris (Figure 3B). Numerous apoptotic cells with characteristically fragmented nuclei were detected in the bronchial epithelium with the terminal dUTP nick-end labeling system (Figure 3C). A few of the apoptotic cells were desquamated to the bronchial lumen, but most cells were situated in vacuoles demonstrating that the phagocytized material described above consisted of apoptotic cells. It was difficult to characterize the phagocytizing cells because of the large vacuoles and the very sparse cytoplasm. In general, CD68-positive mature macrophages were only rarely detected in the bronchial epithelium during the infection. The number of phagocytizing cells and their morphology suggest that the phagocytizing cells were neighboring epithelial cells, but immunostaining with anti-cytokeratin to demonstrate epithelial origin was difficult because of the intense staining of neighboring epithelial cells. Later, on PID 8, many of the alveolar cells were demonstrated to be apoptotic, several of which were phagocytized by other cells. The identity of these alveolar phagocytizing cells are uncertain. Apoptotic cells were not found in the lung of any of the mockinoculated calves.

These results demonstrate that the clearance of virus is very fast and that apoptosis seems to be an important pathway for viral clearance of bronchial epithelium. Some of the apoptotic bronchial cells are detached into the bronchial lumen, but most of the cells are phagocytized probably by neighboring epithelial cells.

Both $\mathrm{CD}^{+}{ }^{+}$and $\mathrm{CD} 8+\mathrm{T}$ lymphocytes were detected in lamina propria of the bronchi in all animals (Table 1). However, the number of $\mathrm{T}$ cells was very low in the control calves. The number of both $\mathrm{CD}^{+}$and CD8+ T cells increased during the infection (Figure 4) even though there were individual differences. In the beginning of infection the T lymphocytes were only found in the lamina propria and submucosa, but not among the epithelial cells. Even in calves killed on PID 6, in which vacuoles containing phagocytized apoptotic cells were seen in the epithelium, there were no $T$ lymphocytes observed among the epithelial cells (Figure 5A). In one animal killed on PID 8, a few CD8+ T cells were present in the epithelium, but at this time apoptosis was no longer detectable in the bronchial epithelium. A higher number of CD8+ T cells was seen among the bronchial epithelial cells in one calf killed on PID 15, and at this time a few CD8+ T cells were detected in the lumen of the bronchi as well (Figure $5 B)$. One of three calves killed on PID 30 had high numbers of both $\mathrm{CD}^{+}$and CD8+ T cells in the lung. This animal still had minor pathological changes, whereas the other two animals had low numbers of $\mathrm{T}$ cells and no pathological changes.
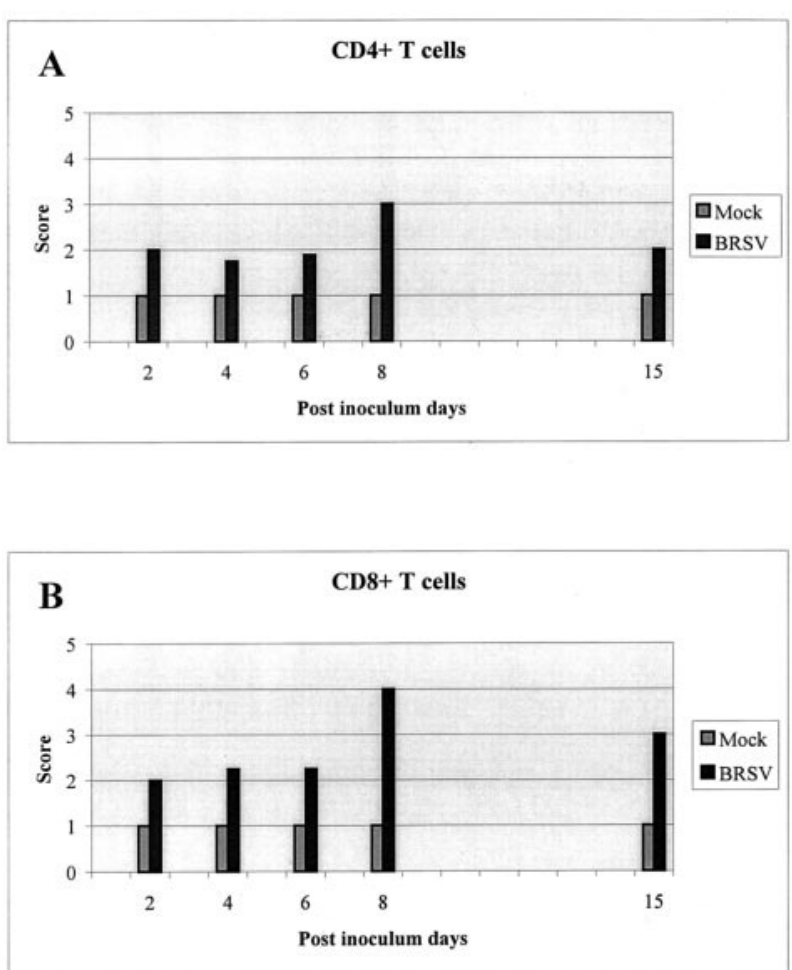

Figure 4. Schematic outline of the presence of $\mathrm{CD}^{+}(\mathbf{A})$ and $\mathrm{CD} 8+(\mathbf{B}) \mathrm{T}$ cells in the lung of mock- and BRSV-inoculated calves. The T-cell score is an average of scores for the animals killed the same PID (see Table 1).

Thus, we see an increasing number of $T$ cells during the infection, but at the time in which apoptotic bronchial epithelial cells are demonstrated both $\mathrm{CD} 4^{+}$and CD8+ T cells are situated in lamina propria with no direct contact with the epithelial cells. However, later during infection, especially on PID 15, both $\mathrm{CD} 4^{+}$and CD8+ T cells can be detected between the bronchial epithelial cells. Because of the consolidation it was not possible to establish the localization of the T cells in the alveoli.

Although BRSV antigen was found in a few alveolar macrophages, these cells did not seem to be the most important cell type for phagocytosis of viral material. As early as PID 2 neutrophils were seen passing through the bronchial epithelium toward the lumen and a moderate number of neutrophils was detected in the lumen of some bronchi. A higher number of neutrophils was seen on PID 4 and some of these cells observed in the lumen of the bronchi did contain BRSV antigen, whereas BRSV antigen was not demonstrated in the neutrophils that were migrating between bronchial epithelial cells toward the lumen. Later, on PID 6 and especially on PID 8, the lumen of bronchi, bronchioles, and alveoli were filled with inflammatory exudate composed predominantly of neutrophils containing an abundant amount of viral antigen (Figure 6A), but not replicating BRSV (Figure 6B) as demonstrated by immunohistochemistry and in situ hybridization, respectively. In comparison, the number of alveolar macrophages was much smaller and only a few contained BRSV antigen. Therefore, the neutrophil is probably the major phagocytizing cell of virus antigen and particles that have reached the bronchial lumen. 

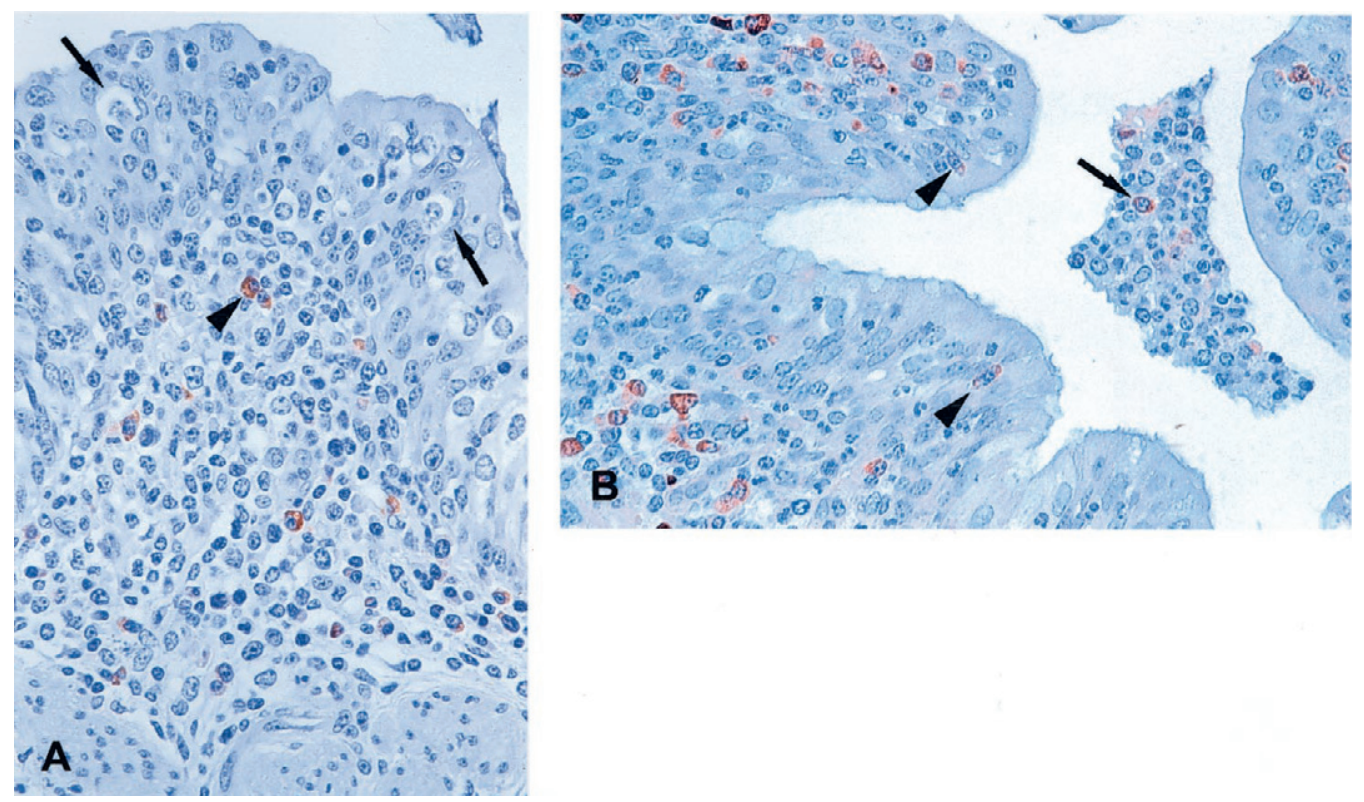

Figure 5. A: BRSV-infected calf XI-3, killed on PID 6. Several vacuoles containing phagocytized apoptotic cells are seen in the epithelium (arrows), but immunohistochemistry using an anti-bovine CD8+ antibody demonstrates no T cells among the epithelial cells. However a moderate number of CD8+ T cells are seen in the lamina propria of the bronchi (arrowhead). Immunohistochemistry, CD8+-positive cells are brown. Hematoxylin counterstain. B: BRSV-infected calf IV-8, killed on PID 15. Immunohistochemistry demonstrates CD8+ T cells among bronchial epithelial cells (arrowheads) and in lamina propria. Furthermore a few CD8+ T cells are detected in the lumen of the bronchi (arrow). Immunohistochemistry, CD8+-positive cells are brown. The inoculum in experiment number IV consisted of lung wash fluid from a BRSV-infected calf whereas BRSV-infected fetal bovine lung cells were used for inoculum in experiment XI. Hematoxylin counterstain. Original magnifications, $\times 100$ (A and $\mathbf{B}$ ).

However, together with mucus and desquamated epithelial cells the neutrophils are also responsible for the obliteration of bronchi and later (PIDs 6 to 8) also the bronchioles and the alveolar lumina. Later, on PID 15, immunostaining using anti-CD68 demonstrated a high number of alveolar macrophages in the alveoli especially in animal IV-8 (Figure 6C). These macrophages, seen late in the course of infection, were large and activated and some of them contained phagocytized neutrophils (Figure 6D). These results demonstrate the importance of neutrophils in the clearance of BRSV situated in the lumen of the airways, whereas the high number of alveolar macrophages observed later during infection seems to be important in clearing neutrophils and debris.

\section{Demonstration of Other Agents}

Apart from BRSV no viruses were detected in any of the calves, whereas mycoplasma and/or ureaplasma were isolated from most calves including mock-inoculated calves without clinical signs or pathological changes (Table 1). H. somnus was isolated from 2 of 10 calves killed on PID 6, and P. multocida was isolated in 2 calves killed on PID 6 and in 1 of 6 calves killed on PID 8. Furthermore, Pasteurella avium was isolated in one of three calves killed on PID 15. The bacteria were only isolated from BRSVinfected calves, but there was no correlation between clinical signs/macroscopic changes and bacterial isolation. Moreover, the calves in experiment XI, which were treated with antibiotics before inoculation and from which no bacteria could be isolated, also developed severe clinical signs and pathological changes. There were no differences in the microscopical changes seen in these calves compared to the other calves killed on PID 6 Bacteria could not be demonstrated either by histochemical or by immunohistochemical methods in the BRSVinfected calves from which bacteria were isolated, whereas bacteria could easily be detected by immunohistochemistry in the included positive control sections (data not shown).

\section{Discussion}

In this study we demonstrate the time course of viral replication and clearance in calves experimentally infected with BRSV. We were able to show that the replication of BRSV started in the upper part of the respiratory tract including the nasal, tracheal, and bronchial epithelium. The replication of BRSV in the bronchial epithelium peaked around PID 4. In contrast, there was no detectable replication in the lower respiratory tract until PID 4 and extensive replication in the bronchiolar and alveolar epithelium was not seen until PID 6.

There was no detectable virus in the lung of a calf killed 45 minutes after inoculation so the precise distribution of inoculum is not known. At PID 2 only a few bronchial epithelial cells were positive for BRSV replication and antigen, whereas there was a high number of positive bronchial epithelial cells on PID 4. The inoculum should in theory reach the alveoli by aerosol inoculation because most droplets were less than $3 \mu \mathrm{m}$. It is possible that the eclipse phase seen in the upper respiratory tract was longer in the lower respiratory tract explaining the delayed onset of replication in the lower respiratory tract. However, it is more likely that the major part of the inoc- 

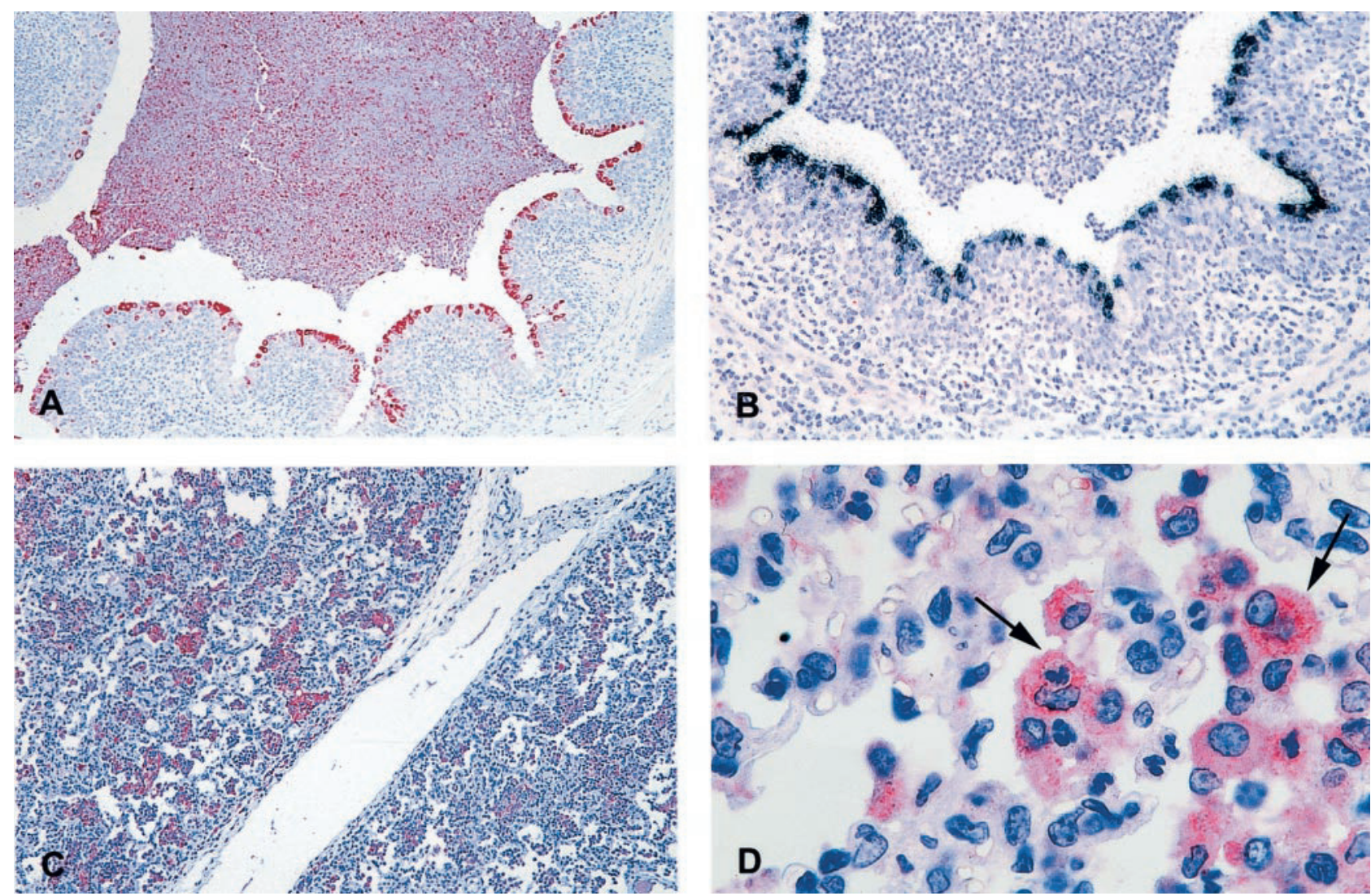

Figure 6. A: BRSV-infected calf XI-3, killed on PID 6. Immunohistochemistry demonstrating BRSV containing neutrophils in the lumen of a bronchi (red cells). BRSV antigen is also detected in some bronchial epithelial cells. Hematoxylin counterstain. B: BRSV-infected calf XI-3, killed on PID 6. In situ hybridization, with a negative sense probe, is demonstrating BRSV-replicating bronchial epithelial cells whereas neutrophils situated in the lumen of the bronchi are not replicating BRSV. Hematoxylin counterstain. C: BRSV-infected calf IV-8, killed on PID 15. Immunohistochemistry using an anti-CD68 antibody to detect mature alveolar macrophages. A high number of macrophages are seen in the alveoli (red cells). Hematoxylin counterstain. D: BRSV-infected calf IV-8, killed on PID 15. Immunohistochemistry demonstrating mature CD68+ macrophages (red cells). Some of the macrophages have ingested neutrophils (arrows). The inoculum in experiment number IV consisted of lung wash fluid from a BRSV-infected calf whereas BRSV-infected fetal bovine lung cells were used for inoculum in experiment XI. Hematoxylin counterstain. Original magnifications: $\times 25(\mathbf{A}$ and $\mathbf{C}) ; \times 50(\mathbf{B}) ; \times 250(\mathbf{D})$.

ulum stuck to the mucus layer of the upper respiratory tract without reaching the alveoli. At the time of extensive viral replication in the bronchial epithelium, the infection then spread downwards to the bronchiolar and alveolar epithelium, maybe as a result of the cilia destruction of the bronchial epithelium. The replication of BRSV was pronounced in the luminal part of the epithelium as also described for HRSV and naturally BRSV-infected calves. ${ }^{20,23}$ Large amounts of BRSV antigen were demonstrated in the cilia of bronchial epithelial cells on PID 4, which led to cilia destruction as described before by electron microscopic examination. ${ }^{24}$

The severe clinical signs with tachypnea and anorexia were not manifested until PID 6, which coincided with maximum replication in the alveolar epithelial cells. Calves with replication restricted to the upper respiratory tract, including the bronchial epithelial cells, were coughing but demonstrated no severe clinical signs. This clinical progression of illness from an upper respiratory tract infection to a lower respiratory tract infection has also been described in young children with HRSV infection ${ }^{1}$ and in immunocompromised human adults. ${ }^{25,26}$ Here we demonstrate a correlation between the progression of clinical signs and viral replication, which may explain why monthly administration of RSV antibodies to high-risk children seems to be effective in reducing the numbers of severe respiratory disease in young children. ${ }^{27}$ The presence of high levels of antibodies might prevent a spread of viral replication to the lower part of the respiratory tract thereby preventing severe disease.

Although the number of mature alveolar macrophages increased during the experimental BRSV infection, they only rarely contained BRSV antigen. Instead we found that the large BRSV-replicating cells in the alveoli were alveolar type II epithelial cells. Thus, although we cannot rule out that a small subpopulation of alveolar macrophages can replicate BRSV as described by in vitro studies, ${ }^{28}$ the epithelial cells are by far more important for virus replication. Furthermore, our results indicate that the alveolar macrophages only play a minor role in phagocytizing BRSV, whereas they seemed to be important for phagocytizing neutrophils in the process of repair (PID 15).

A high number of neutrophils were seen in the lumen of the bronchi as early as PID 2. BRSV antigen was demonstrated in the neutrophils from PID 4 and later (PIDs 6 to 8) they contained high amounts of antigen, however, sense-specific in situ hybridization revealed that these cells did not replicate virus. The lumen of bronchi, bron- 
chioles, and later alveoli were often plugged with cellular debris consisting mostly of neutrophils but later mixed with desquamated epithelial cells and macrophages. This plugging by cellular debris has also been described in autopsy studies of infants and young children after fatal HRSV infection. ${ }^{23,29,30}$ However, in some cases the main changes in children were described to be mononuclear infiltration. ${ }^{29}$ This variance is probably caused by different duration of infection because we also observed an increased infiltration by $T$ cells and macrophages during infection. Similar to our studies, analysis of cells obtained by bronchial lavage of infants with HRSV infection demonstrated excessive numbers of neutrophils in both the upper and lower airway. ${ }^{31}$ Our study shows that the neutrophils are important for clearance of BRSV excreted into the lumen of the respiratory tract, whereas neutrophils migrating through the bronchial epithelium did not contain BRSV antigen. Further investigations are needed to determine whether the neutrophils might contribute to the observed tissue damage by releasing inflammatory products. However, the blocking of the airways by neutrophils is probably part of the reason for the advanced respiratory distress; and the emphysema seen especially on PID 8 might be caused by trapped air.

The clearance of virus in the BRSV-infected calves elapsed in the same order as the replication. Already on PID 8 the virus had been cleared from the bronchial epithelium and even the BRSV antigen could no longer be detected. Because no calves were killed between PID 8 and PID 15, we have only shown that the replication in the alveoli stopped before PID 15. This leaves a very short time, after the onset of clinical signs, for demonstrating BRSV by virus isolation or antigen demonstration, which is diagnostically important. Furthermore, these findings may explain some of the cases in which HRSV could not be detected postmortem by immunohistochemistry although the virus was demonstrated antemortem. ${ }^{23,32}$

In this study we were able to demonstrate that apoptosis was an important way of BRSV clearance. A large number of apoptotic cells was detected in bronchial epithelium on PID 6, and apoptotic BRSV antigen-containing cells were seen in vacuoles of phagocytizing cells. When regarding that the whole apoptotic process, from development of morphological changes to degradation of phagocytized apoptotic material, has been described to be completed in an hour or so, ${ }^{33}$ this process seemed to be the major way of viral clearance in the bronchial epithelium. The phagocytizing cells in the epithelium were mononuclear, but because of the large vacuoles and sparse cytoplasm in these cells, it was difficult to identify the cell type. However, they were probably not macrophages because the number of CD68-positive mature macrophages in the epithelium was very low compared to the high number of phagocytizing cells. Instead it is more likely that the phagocytizing cells were neighboring epithelial cells. Phagocytosis of apoptotic cells by neighboring cells has also been suggested after physiological apoptosis in hormone-dependent tissues ${ }^{34}$ and in the normal colonic mucosa. ${ }^{35}$
CD8+ T cells have been described to be important for viral clearance in the lungs of RSV-infected mice and in BRSV-infected gnotobiotic calves. ${ }^{36,37}$ In the present study, we demonstrated an increasing number of CD8+ $T$ cells in the lungs during infection, but until PID 8 these $T$ cells were not demonstrated in the epithelium of the bronchi. On PID 6, when apoptosis was detected in the bronchial epithelium, CD8+ T cells could not be demonstrated among the bronchial epithelial cells in any of the eight BRSV-infected calves, whereas a moderate number of CD8+ T cells was detected in lamina propria of the bronchi in these calves. Later in the course of infection (PID 15), a few CD8 + T cells were seen in the bronchial epithelium and lumen of bronchi in one calf suggesting an impeded passage into the bronchial epithelium and lumen of the bronchi before PIDs 8 to 15. This is consistent with a study in BRSV-infected gnotobiotic calves in which an increased number of CD8+ T cells was observed by flow cytometry in bovine lung tissue from PIDs 3 to 5 but not in bronchoalveolar lavage until 10 to 15 days after infection. ${ }^{38}$ As for the CD8+ T cells, we saw an increasing number of $\mathrm{CD} 4^{+} \mathrm{T}$ cells during the infection, and likewise, the $\mathrm{CD} 4^{+} \mathrm{T}$ cells were not detected among the bronchial epithelial cells until PID 8.

Killing by cytotoxic $T$ cells is generally described to occur either by granzyme/perforin mediated lysis of target cells or by Fas ligand (FasL)/Fas interaction; ${ }^{39}$ both pathways requiring a direct cell-to-cell contact. However, our study indicates that the efficient clearance of BRSV from the bronchial epithelium is mediated by another mechanism than contact-dependent T-cell-mediated cytotoxicity. In vitro studies using a lung epithelial cell line (A549) has demonstrated that both Fas and FasL were up-regulated after infection with RSV, ${ }^{40,41}$ however, absent inhibition of apoptosis after blocking the Fas/FasL pathway suggested a limited role of the Fas/FasL pathway in RSV-induced apoptosis of A549 cells. ${ }^{41}$ Because of a strong activation of caspase-12 the authors instead suggested that a direct RSV-induced apoptosis occurred through an endoplasmic reticulum stress response. ${ }^{41}$

There is an increasing amount of data suggesting that direct contact-dependent cytolysis of virus-infected cells by cytotoxic $T$ lymphocytes is not the only way of viral clearance. ${ }^{42}$ It seems that some cytopathic viruses are mainly controlled by soluble mediators such as antibodies and cytokines produced in the immediate vicinity of an infected cell. ${ }^{43}$ Interestingly, we have previously detected high levels of tumor necrosis factor- $\alpha$ (TNF- $\alpha$ ) in lung lavage of experimental BRSV-infected calves killed on PIDs 6 and $7 .{ }^{44}$ In contrast, the level of TNF- $\alpha$ was low or not detectable in calves killed before PID 6 and in mock-inoculated calves. It is, therefore, possible that this local production of TNF- $\alpha$ is important for the RSV clearance by inducing apoptosis; maybe in combination with a noncytopathic mechanism as described for hepatitis B virus in which in vivo studies in mice have shown that anti-viral cytokines (especially interferon- $\gamma$ and TNF- $\alpha$ ) released by virus-specific cytotoxic $T$ Iymphocytes were able to purge virus from infected cells in a noncytopathic manner. ${ }^{45,46}$ Further studies are necessary to reveal if the 
TNF- $\alpha$ is produced by the T cell situated in the lamina propria.

Interestingly, a recent study by Aung and colleagues ${ }^{47}$ demonstrates that perforin knockout mice were able to clear RSV by day 10 just as RSV-infected wild-type mice although the perforin knockout mice had higher levels of virus on PIDs 6 and 8. Furthermore, the perforin knockout mice showed enhanced disease together with increased and prolonged production of interferon- $\gamma$ and TNF- $\alpha$. These observations are consistent with our results demonstrating that a direct contact-dependent mechanism might not be the main mechanism of RSV clearance. However, our observations of a T-cell contact-independent mechanism of viral clearance only apply for the bronchial infection. We can demonstrate widespread apoptosis in the alveoli on PID 8 and these apoptotic alveolar cells were also phagocytized, but it was not possible to identify the phagocytizing cells and it was impossible to decide whether there was direct cell contact to T cells.

Several animal models of RSV have been developed and all have their drawbacks. ${ }^{13}$ The problem in this calf model is the co-infections with mycoplasma, ureaplasma, and in some animals also bacteria. However, mycoplasma was also detected in mock-inoculated calves without clinical signs and pathological changes. Furthermore, the BRSV-infected calves, from which bacteria and mycoplasma had been isolated, had similar clinical signs and pathological changes as seen in BRSV-infected calves without co-infections. Therefore, we conclude that the co-infections have no significant influence on the replication and clearance of BRSV studied in this experimental model.

The fact that severe clinical signs and pathological changes continue after clearance of virus supports the assumption of an exaggerated immune response to be important in the pathogenesis. However, our results demonstrate that the severe pathological changes appear when replication of RSV spreads to the alveoli. Moreover, the fact that RSV infection in immunocompromised infants and adults causes severe and even fatal lower respiratory tract disease shows that the amount of virus replication also is important for the pathogenesis as these individuals have prolonged RSV excretion. ${ }^{25,26,48}$ This indicates that both a vigorous host immune response and an insufficient restriction of viral replication can contribute to development of severe disease.

The high level of replication in this calf model makes it a very good model for studies of replication and clearance of RSV. We can conclude that apoptosis is an important way of clearing BRSV-infected bronchial epithelial cells probably followed by phagocytosis by neighboring epithelial cells, whereas neutrophils are important for clearance of virus situated in the lumen of the respiratory tract. Increasing infiltration with CD8 $+\mathrm{T}$ cells was seen during infection, but they could not be demonstrated between the bronchial epithelial cells until PIDs 8 to 15 when viral replication no longer could be demonstrated in the bronchial epithelial cells. This suggests that there is no direct contact-dependent CD8+ T-cell-mediated cytotoxicity involved in the clearance of virus in the primary infection. However, this observation only relates to the bronchi. On PID 8 there is a high number of apoptotic cells in the alveoli as well, but because of the anatomical structure and the severe alveolitis it is not possible to determine whether or not the CD8+ cells are in close contact with the apoptotic cells. Further investigations are required to study this issue.

\section{Acknowledgments}

We thank Dr. Conny Tegtmeier, Danish Veterinary Institute, Denmark, for providing the antibodies against $H$. somnus and $P$. multocida and the positive control sections; and Mette Bak, Lisbet Kiørboe, and Rukhsana Hafiz for excellent technical assistance.

\section{References}

1. Hall CB: Respiratory syncytial virus: a continuing culprit and conundrum. J Pediatr 1999, 135:2-7

2. Falsey $A R$, Walsh EE: Respiratory syncytial virus infection in adults Clin Microbiol Rev 2000, 13:371-384

3. Kim HW, Canchola JG, Brandt CD, Pyles G, Chanock RM, Jensen K, Parrott $\mathrm{RH}$ : Respiratory syncytial virus disease in infants despite prior administration of antigenic inactivated vaccine. Am J Epidemiol 1969, 89:422-434

4. Kapikian AZ, Mitchell RH, Chanock RM, Shvedoff RA, Stewart CE: An epidemiologic study of altered clinical reactivity to respiratory syncytial (RS) virus infection in children previously vaccinated with an inactivated RS virus vaccine. Am J Epidemiol 1969, 89:405-421

5. Graham BS: Pathogenesis of respiratory syncytial virus vaccine-aug mented pathology. Am J Respir Crit Care Med 1995, 152:S63-S66

6. Collins PL, Whitehead SS, Bukreyev A, Fearns R, Teng MN, Juhasz K, Chanock RM, Murphy BR: Rational design of live-attenuated recombinant vaccine virus for human respiratory syncytial virus by reverse genetics. Adv Virus Res 1999, 54:423-451

7. Chanock RM, Kapikian AZ, Mills J, Kim HW, Parrott RH: Influence of immunological factors in respiratory syncytial virus disease. Arch Environ Health 1970, 21:347-355

8. Prince GA, Hemming VG, Horswood RL, Baron PA, Chanock RM Effectiveness of topically administered neutralizing antibodies in experimental immunotherapy of respiratory syncytial virus infection in cotton rats. J Virol 1987, 61:1851-1854

9. Hemming VG, Rodriguez W, Kim HW, Brandt CD, Parrott RH, Burch B, Prince GA, Baron PA, Fink RJ, Reaman G: Intravenous immunoglobulin treatment of respiratory syncytial virus infections in infants and young children. Antimicrob Agents Chemother 1987, 31:18821886

10. Prince GA, Mathews A, Curtis SJ, Porter DD: Treatment of respiratory syncytial virus bronchiolitis and pneumonia in a cotton rat model with systemically administered monoclonal antibody (Palivizumab) and glucocorticosteroid. J Infect Dis 2000, 182:1326-1330

11. Kim HW, Leikin SL, Arrobio J, Brandt CD, Chanock RM, Parrott RH: Cell-mediated immunity to respiratory syncytial virus induced by inactivated vaccine or by infection. Pediatr Res 1976, 10:75-78

12. Openshaw PJ: Immunity and immunopathology to respiratory syncytial virus. The mouse model. Am J Respir Crit Care Med 1995, 152:S59-S62

13. Byrd LG, Prince GA: Animal models of respiratory syncytial virus infection. Clin Infect Dis 1997, 25:1363-1368

14. Uttenthal A, Larsen LE, Philipsen JS, Tjornehoj K, Viuff B, Nielsen KH, Nielsen TK: Antibody dynamics in BRSV-infected Danish dairy herds as determined by isotype-specific immunoglobulins. Vet Microbiol 2000, 76:329-341

15. Larsen LE, Uttenthal A, Arctander P, Tjornehoj K, Viuff B, Rontved C, Ronsholt L, Alexandersen S, Blixenkrone-Moller M: Serological and genetic characterisation of bovine respiratory syncytial virus (BRSV) indicates that Danish isolates belong to the intermediate subgroup: no evidence of a selective effect on the variability of $G$ protein 
nucleotide sequence by prior cell culture adaption and passages in cell culture or calves. Vet Microbiol 1998, 62:265-279

16. Tjørnehøj K, Uttenthal Å, Viuff B, Larsen LE, Røntved C, Rønsholt L: An experimental infection model for reproduction of calf pneumonia with bovine respiratory syncytial virus (BRSV) based on one combined exposure of calves. Res Vet Sci (in press)

17. Larsen LE, Tjornehoj K, Viuff B, Jensen NE, Uttenthal A: Diagnosis of enzootic pneumonia in Danish cattle: reverse transcription-polymerase chain reaction assay for detection of bovine respiratory syncytial virus in naturally and experimentally infected cattle. J Vet Diagn Invest 1999, 11:416-422

18. Uttenthal A, Jensen NP, Blom JY: Viral aetiology of enzootic pneumonia in Danish dairy herds: diagnostic tools and epidemiology. Vet Rec 1996, 139:114-117

19. Tegtmeier C, Uttenthal A, Friis NF, Jensen NE, Jensen HE: Pathological and microbiological studies on pneumonic lungs from Danish calves. Zentralbl Veterinarmed [B ] 1999, 46:693-700

20. Viuff B, Uttenthal A, Tegtmeier C, Alexandersen S: Sites of replication of bovine respiratory syncytial virus in naturally infected calves as determined by in situ hybridization. Vet Pathol 1996, 33:383-390

21. Tegtmeier C, Jensen NE, Jensen HE: Development of a peroxidaseantiperoxidase (PAP) technique for the identification of Haemophilus somnus in pneumonic calf lungs in Denmark. APMIS 1995, 103:540547

22. Bryson DG: Necropsy findings associated with BRSV pneumonia. Vet Med 1993, 88:894-899

23. Neilson KA, Yunis EJ: Demonstration of respiratory syncytial virus in an autopsy series. Pediatr Pathol 1990, 10:491-502

24. Bryson DG, Platten MF, McConnell S, McNulty MS: Ultrastructural features of lesions in bronchiolar epithelium in induced respiratory syncytial virus pneumonia of calves. Vet Pathol 1991, 28:293-299

25. Hertz MI, Englund JA, Snover D, Bitterman PB, McGlave PB: Respiratory syncytial virus-induced acute lung injury in adult patients with bone marrow transplants: a clinical approach and review of the literature. Medicine (Baltimore) 1989, 68:269-281

26. Harrington RD, Hooton TM, Hackman RC, Storch GA, Osborne B, Gleaves CA, Benson A, Meyers JD: An outbreak of respiratory syncytial virus in a bone marrow transplant center. J Infect Dis 1992 , 165:987-993

27. Simoes EA: Respiratory syncytial virus infection. Lancet 1999, 354: 847-852

28. Schrijver RS, Kramps JA, Middel WG, Langedijk JP, van Oirschot JT: Bovine respiratory syncytial virus replicates minimally in bovine alveolar macrophages. Arch Virol 1995, 140:1905-1917

29. Aherne W, Bird T, Court SD, Gardner PS, McQuillin J: Pathological changes in virus infections of the lower respiratory tract in children. J Clin Pathol 1970, 23:7-18

30. Gardner PS: How etiologic, pathologic, and clinical diagnoses can be made in a correlated fashion. Pediatr Res 1977, 11:254-261

31. Everard ML, Swarbrick A, Wrightham M, Mclntyre J, Dunkley C, James PD, Sewell HF, Milner AD: Analysis of cells obtained by bronchial lavage of infants with respiratory syncytial virus infection. Arch Dis Child 1994, 71:428-432
32. MacDonald NE, Hall CB, Suffin SC, Alexson C, Harris PJ, Manning JA: Respiratory syncytial viral infection in infants with congenital heart disease. N Engl J Med 1982, 307:397-400

33. Savill J: Apoptosis in resolution of inflammation. J Leukoc Biol 1997, 61:375-380

34. Marti A, Jaggi R, Vallan C, Ritter PM, Baltzer A, Srinivasan A, Dharmarajan AM, Friis RR: Physiological apoptosis in hormone-dependent tissues: involvement of caspases. Cell Death Differ 1999, 6:11901200

35. Strater J, Koretz K, Gunthert AR, Moller P: In situ detection of enterocytic apoptosis in normal colonic mucosa and in familial adenomatous polyposis. Gut 1995, 37:819-825

36. Cannon MJ, Openshaw PJ, Askonas BA: Cytotoxic T cells clear virus but augment lung pathology in mice infected with respiratory syncytial virus. J Exp Med 1988, 168:1163-1168

37. Taylor G, Thomas LH, Wyld SG, Furze J, Sopp P, Howard CJ: Role of T-lymphocyte subsets in recovery from respiratory syncytial virus infection in calves. J Virol 1995, 69:6658-6664

38. Mcinnes E, Sopp P, Howard CJ, Taylor G: Phenotypic analysis of local cellular responses in calves infected with bovine respiratory syncytial virus. Immunology 1999, 96:396-403

39. Pinkoski MJ, Green DR: Fas ligand, death gene. Cell Death Differ 1999, 6:1174-1181

40. O'Donnell DR, Milligan L, Stark JM: Induction of CD95 (Fas) and apoptosis in respiratory epithelial cell cultures following respiratory syncytial virus infection. Virology 1999, 257:198-207

41. Bitko V, Barik S: An endoplasmic reticulum-specific stress-activated caspase (caspase-12) is implicated in the apoptosis of A549 epithelial cells by respiratory syncytial virus. J Cell Biochem 2001, 80:441-454

42. Bloom B, Zinkernagel R: Immunity to infection. Curr Opin Immunol 1996, 8:465-466

43. Kagi D, Hengartner $H$ : Different roles for cytotoxic $T$ cells in the control of infections with cytopathic versus noncytopathic viruses. Curr Opin Immunol 1996, 8:472-477

44. Rontved CM, Tjornehoj K, Viuff B, Larsen LE, Godson DL, Ronsholt L, Alexandersen S: Increased pulmonary secretion of tumor necrosis factor-alpha in calves experimentally infected with bovine respiratory syncytial virus. Vet Immunol Immunopathol 2000, 76:199-214

45. Guidotti LG, Ando K, Hobbs MV, Ishikawa T, Runkel L, Schreiber RD, Chisari FV: Cytotoxic T lymphocytes inhibit hepatitis B virus gene expression by a noncytolytic mechanism in transgenic mice. Proc Natl Acad Sci USA 1994, 91:3764-3768

46. Guidotti LG, Ishikawa T, Hobbs MV, Matzke B, Schreiber R, Chisari FV: Intracellular inactivation of the hepatitis B virus by cytotoxic $T$ lymphocytes. Immunity 1996, 4:25-36

47. Aung S, Rutigliano JA, Graham BS: Alternative mechanisms of respiratory syncytial virus clearance in perforin knockout mice lead to enhanced disease. J Virol 2001, 75:9918-9924

48. Hall CB, Powell KR, MacDonald NE, Gala CL, Menegus ME, Suffin SC, Cohen HJ: Respiratory syncytial viral infection in children with compromised immune function. N Engl J Med 1986, 315:77-81 